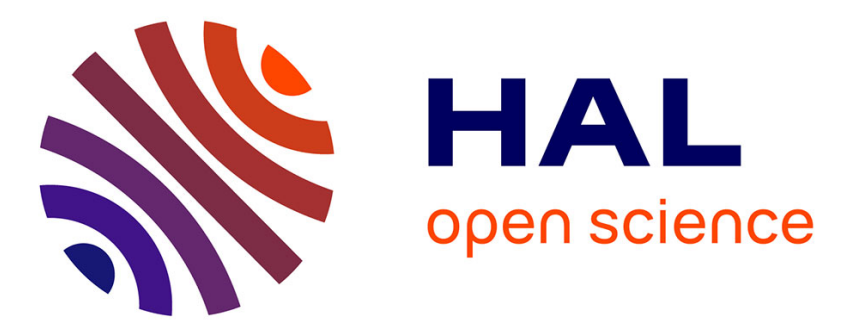

\title{
The Moriscos in France after the Expulsion: Notes for the History of a Minority
}

\author{
Youssef El Alaoui
}

\section{To cite this version:}

Youssef El Alaoui. The Moriscos in France after the Expulsion: Notes for the History of a Minority. Mercedes García-Arenal et Gerard Wiegers. The expulsion of the Moriscos from Spain. A Mediterranean Diaspora, 56, Brill, pp.239-268, 2014, The Medieval and Early Modern Iberian World, 978-90-04-25920-I. halshs-02422638

\section{HAL Id: halshs-02422638 https://shs.hal.science/halshs-02422638}

Submitted on 4 Nov 2020

HAL is a multi-disciplinary open access archive for the deposit and dissemination of scientific research documents, whether they are published or not. The documents may come from teaching and research institutions in France or abroad, or from public or private research centers.
L'archive ouverte pluridisciplinaire HAL, est destinée au dépôt et à la diffusion de documents scientifiques de niveau recherche, publiés ou non, émanant des établissements d'enseignement et de recherche français ou étrangers, des laboratoires publics ou privés. 


\title{
The Expulsion of the Moriscos from Spain
}

A Mediterranean Diaspora

\author{
Edited by \\ Mercedes García-Arenal \\ Gerard Wiegers
}

Translated by

Consuelo López-Morillas

Martin Beagles

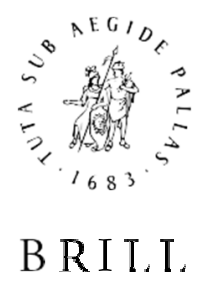

LEIDEN |BOSTON 


\section{The Moriscos in France after the Expulsion Notes for the History of a Minority}

\section{Youssef El Alaoui}

TheExpulsion of the Moriscosfrom Spain did not pass unnoticed among those living at the time, not only in Muslim countriesl but also in Christian ones like France, which would come to play, very unwillingly, a secondary role in the tragedy.

Cardinal Richelieu, in his memoirs, mentions the event in the year 1610. In four pages he offers us the view of an outsider who, though he was not yet leading the country - he would become the all-powerful prime minister and favourite of Louis XIII from 1624 to 1642 - seems to have been very well informed and aware of the Moriscos' history (although he would inflate, like

1 LuisF.BernabéPons, "Notas sobrela cohesión de lacomunidad morisca más allá de su expulsión de España," Al-Qanțara 29-2 (2008), 307-332, esp. 7-8. We can illustrate the concern of the Ottoman authorities for the fate of the exiled Moriscos with this description of an embarkation of Moriscos at Agde under the supervision of an Ottoman ambassador: "All these Moriscos are naturally sly, using all sorts of frauds, tricks and subversions: they put no trust in strangers and show little charity to one another. The Sieur d'Augier was well aware of this atAgde, where thelargestembarkation tookplace.Hachy-YbrahimMutafaracca, the deputy ambassador of the Grand Turk in France, arrived there in early August to observe the conditions under which the said Moriscos were being deported; and having witnessed the embarkation of four thousand of them, and learned of the good treatment that they all had received from the officers of His Most Christian Majesty, he departed for Barbary to give orders for their reception there" ("Tous ces Morisques sont naturellement subtils, usans de toutes sortes de fraudes, de supercheries et trahisons: ils ne gardent point la foy aux estrangers, sont peu charitables entr'eux-mesmes: cequele sieurd'Augierreconûtassezà Agdeoùle plus grand embarquement s'est fait: et où au commencement du mois d'Aoust arriva HachyYbrahim Mutafaracca député Ambassadeurdu grand Turc enFrance, pour apprendrel'estat de l'embarquement desdits Morisques, lequel ayant veu embarquer quatre mil d'iceux, et appris le bon traitement que tous en général avoient receu des commissaires de sa Majesté très chrestienne, ils'enallaen Barbarie donnerordreà les y faire recevoir'): in Pierre D'Avity, Les estats, empires, royaumes et principautez du monde (Geneve: J.A.\&S. de Tournes), 1665, 145. See also Gerard Wiegers, who notes "the growing tendency in the Ottoman policies noticed by al-Hajarî in Paris: to consider them [the Moriscos] Ottoman subjects in need of and entitled to protection": in "Managing Disaster: Networks of the Moriscos during the Process of the Expulsion from the Iberian Peninsula around 1609," Journal of Medieval Religious Cultures 36-2 (2010), 151. 
many others, the number of the expelled, placing it at 800,000). For Richelieu, what took place in 1610 was "the most rash and barbarous advice that the history of all previous centuries has recorded": he refers, of course, to the Expulsion of the Moriscos, who, he claims, were cast out of their native country after having been abused, despised and treated as slaves. He compares this Expulsion or transmigration to the exodus of the Jews from Egypt, concluding that the fate of the Moriscos was even more cruel: for whereas the Jews had asked to be allowed to return to their own land, the Moriscos were being expelled from theirs:

We can count more than eight hundred thousand of these people, so that this transmigration was no less than that of the Jews from Egypt; there being however these two differences between the two, that in the first case the Hebrews forced the Egyptians to let them leave, while in the second the Moriscos were forced to depart; in the first, the Hebrews left a foreign land in order to sacrifice to God and arrived in a fertile one that had been promised to them, while in the second the Moriscos left their native land to pass into an unknown one where they would have to live as strangers, and in great danger of abandoning the true worship of God.

In a climate of hostility between the two powers, this would be an occasion for France, "whichis famed in all the world as arefugeforthe afflicted," to show its generosity and piety by welcoming those who professed the Catholic faith and facilitating passage to Islamic lands for those who preferred to cleave to their ancestral religion. 2

2 "Le plus hardi et le plus barbare conseil dont l'histoire de tous les siècles précédens fasse mention"; "On fait compte de plus de huit cent mille de ces gens; de sorte que cette transmigration ne fut pas moindre que celle des Juifs hors d'Égypte; y ayant toutefois ces deux différences entre les deux, qu'en celle-là les hébreux contraignoirent les Egyptiens de les laisser aller, en celle-ci les Morisques sont contraints de sortir; en celle-là les Hébreux s'en vont d'une terre étrangère pour sacrifier à Dieu, et passer en une abondante qui leur étoit promise; en celle-ci les Morisques sortent de leur pays natal pour passer en une terre inconnue, où ils doivent vivre comme étrangers, non sans grand hasard d' abandonner le vrai culte deDieu"; "[laFrance], qui est réputé[e] par tout le mondel'asile des afligés": "Mémoires du Cardinal de Richelieu," edited by M. Petitot in Collection des mémoires relatifs à l'Histoire de France, XXI (Paris: Foucault), 1823, 231-234: [231] "Nonetheless before this year [1610] is over, I cannot help but mention that it produced in Spain the most rash and barbarous advice that the history of all previous centuries has recorded, one that gave France the opportunity to give proof of both its humanity and its piety." 
Although there are few contemporary accounts of the events, Spain's action continued to be judged in a negative light, as we see in the authors who dealt with the Expulsion in the nineteenth and early twentieth centuries, returning to the same sources over and over. The historian Henri Martin, for example,

"Spain was full of Moriscos, who were so called because they descended from father to son from the Moors, who in former times had conquered it and ruled it for seven hundred years.

"The ill treatment that they received, and the scorn that they suffered from the Old Christians, caused most of them to preserve in secret their ancestors' impiety and false religion against God, on account of the particular hatred that they felt toward men. [232] As they were treated like slaves, they sought the means of gaining their freedom; and because they were suspected of this all their arms were taken away,especially in the Kingdoms of Granada and Valencia, where nearly all the population was infected with this poison; they were not even allowed to carry knives, unless these were blunted.

"Spain's Council [of State], bearing in mind that the late King [PhilipII] had long takenup the cause against them, feared at the same time that these people would seize the occasion to light the spark of civil war in the heart of their country. To prevent this plan - which was not without foundation - the Catholic King issued, at the beginning of this year, a command that all of them, with their wives and children, depart from Spain within the space of thirty days; during that time they were permitted to sell all their moveable property and take its price with them, not in money but in allowable goods, while all their real estate would be confiscated by the King and added to his domain.

"Those who lived close to the sea took passage for Barbary, and for the purpose, all the foreign ships that were then in the ports were seized; the rest set out for the French border, in order to pass through the King's lands.

"It is impossible to describe the pity inspired by these poor people, stripped of all their belongings, banished from the land of their birth; those who were Christians, and they were not few in number, deserved even greater compassion for being sent, [233] like the others, to Barbary, where they could not help but be in clear danger of adopting the Mohammedan religion against theirwill.

"You would see women with an infant at their breast, a rosary in their hands, dissolved in tears and tearing their hair from despair at their wretched state, calling for help on Jesus Christ and the Virgin, whom they were being forced to abandon.

"The Duke of Medina [Sidonia], admiral of the Andalusian coast, notified the Council of State of this deplorable situation; but he was commanded anew to spare neither age, nor sex, nor condition, the reasons of State forcing him to deport the good along with the bad. The Duke was forced to obey against his will, saying aloud that it was easy to order from afar a measure that could not be carried out without great sorrow.

"We can count more than eight hundred thousand of these people; so that this transmigration was no less than that of the Jews from Egypt; there being however these two differences between the two, that in the first case the Hebrews forced the Egyptians to let them leave, while in the second the Moriscos were forced to depart; in the first, the Hebrews left a foreign land in order to sacrifice to God and arrived in a fertile one that had been promised to them, while in the second the Moriscos left their native land to pass into an unknown one 
dedicated several pages of his 1857 history of France to the Morisco drama: employing, like Richelieu, a Biblical simile, he thought that

we have to return to the conquests of the ancient East, to vanquished peoples who were dragged from theirhomes en masse, to the Babylonian captivity, to find scenes comparable to the one that Europe witnessed in

where they would have to live as strangers, and in great danger of abandoning the true worship of God.

"King Henry [IV] the Great, hearing that many of these poor people were traveling the roads of his kingdom, which [234] is famed in all the world as a refuge for the afflicted, moved by pity for their suffering, issued a decree requiring that his lieutenants and officers inform them, at the border, that those who wished to follow the Catholic religion and declare it before the bishop of Bayonne would then be allowed to remain in his States on this side of the Garonne and Dordogne Rivers; there they would be received if they made profession of their faith before the bishop of the diocese in which they wished to reside.

"As for those who wished to live in the sect of Mohammed, they would be provided with the ships needed to take them to Barbary.

"The death of this great prince prevented his decree from being carried out, but the queen took it on herself to see it done.” ([231] “Cependant avant que clore cette année [1610], je ne puis que je ne rapporte qu' elle produisit en Espagne le plus hardi et le plus barbare conseil dont l'histoire de tous les siècles précédens fasse mention; ce qui donna lieu à la France de rendre un témoignage de son humanité et de sa piété tout ensemble.

L'Espagne étoit remplie de Morisques, qui étoient ainsi appelés, parce que de père en fils ils descendoient des Mores, qui l'avoient autrefois subjuguée et commandée sept cents ans durant.

Le mauvais traitement qu'ils recevoient, et le mépris, et le mépris qu'ils souffroient des vieux chrétiens, firentque laplus grande partd'entre eux conservèrent secrètementl'impiété et fausse religion de leurs ancêtres contre Dieu, pour la haine particulière qu'ils avoient contre les hommes. [232] Étant traités comme esclaves, ils cherchent les moyens de se mettre en liberté; le soupçon qu'on en a, fait qu' on leurôte toutes leurs armes, et particulièrement aux royaumes de Grenade et de Valence, où tout le peuple étoit presque infecté de ce venin; il ne leur étoit même pas permis de porter des couteaux, s'ils n'étoient épointés.

Le Conseil d'Espagne, considérant que le feu roi s'engageoit en une grande entreprise contre eux, eut en même temps appréhension que ces peuples prissent cette occasion d'allumer une guerre civile dans le cœur de leurs États. Pour prévenir ce dessein qui n'étoit pas sans fondement, le Roi Catholique fit, au commencement de cette année, un commandement à tous ces gens-là de sortir d'Espagne, avec leurs femmes et leurs enfans, dans trente jours pour tout délai, pendant lesquels il leur étoit permis de vendre tous les meubles, et en porter avec eux le prix, non en argent, mais en marchandises du pays non défendues, tous leurs immeubles demeurant confisqués au Roi et réunis à son domaine.

Ceux qui étoient près de la mer s'embarquèrent pour passer en Barbarie, et, pource sujet, tous les vaisseaux étrangers qui étoient dans leurs ports furent arrêtés; les autres prirent le chemin de la frontière de la France pour passer par les États du Roi. 
the seventeenth century! The responsibility for this great assault on humanity falls entirely on Spanish Catholicism: the Papacy refused to associate itself with it. So implacable against domestic enemies, against heretics, [Spain] did not feel the same fury against the enemy from without, Islam. The Spanish Court could not persuade Paul V to join in condemning an entirepeople. 3

Il est impossible de représenter la pitié que faisoit ce pauvre peuple, dépouillé de tous ses biens, banni du pays de sa naissance; ceux qui étoient chrétiens, qui n'étoient pas en petit nombre, étaient encore dignes d'une plus grande compassion, pour être envoyés, [233] comme les autres, en Barbarie, où ils ne pouvoient qu'être en péril évident de reprendre contre leur gré la religion mahométane.

On voyait les femmes avec leurs enfans à la mamelle, les chapelets en leur main, qui fondoient en larmes et s'arrachoient les cheveux de désespoir de leur misère, et appeler Jésus-Christ et la Vierge, qu'on les contraignoit d'abandonner, à leur aide.

Le duc de Medina, amiral de la côte d'Andalousie, donna avis au Conseil d'Espagne de cette déplorable désolation; mais il reçut un nouveau commandement de n'épargner âge, sexe, ni condition, la raison d'État contraignant à faire partir les bons avec les méchans; ce qui obligea le duc à obéir, contre son gré, disant hautement qu'il étoit bien aisé de commander de loin ce qu'il étoit impossible d'exécuter sans compassion extrême.

On fait compte de plus de huit cent mille de ces gens; de sorte que cette transmigration ne fut pas moindrequecelle des Juifs hors d'Égypte; y ayant toutefoisces deux différencesentre les deux, qu'encelle-làles hébreux contraignoirent lesEgyptiens deles laisser aller, en celleci les Morisques sont contraints de sortir; en celle-là les Hébreux s'en vont d'une terre étrangère pour sacrifier à Dieu, et passer en une abondante qui leur étoit promise; en celle-ci les Morisques sortent de leur pays natal pour passer en une terre inconnue, où ils doivent vivre comme étrangers, non sans grand hasard d'abandonner le vrai culte de Dieu.

Le roi Henri-le-Grand, ayant avis que plusieurs de ces pauvres gens s'achemionoient en son royaume, qui [234] estréputé partoutlemondel'asile des affligés, touchéde compassion de leur misère, fit publierune ordonnance qui obligeoit ses lieutenants et officiers à leur faire entendre, sur la frontière, que ceux qui voudroient vivre en la religion catholique, en faisant profession devant l'évêque de Bayonne, auroient ensuite permission de demeurer en ses États, au-deçà des rivières de Garonne et Dordogne, où ils seroient reçus faisant apparoître à l'évêque du diocèse où ils voudroient s' habituer, de l'acte de leur profession de foi.

Et quant aux autres qui voudroient vivre en la secte de Mahomet, on leur pourvoiroit de vaisseaux nécessaires pour les faire passer en Barbarie.

La mort de ce grand prince prévint l'exécution de son ordonnance, mais la reine la fit exécuter avec soin.”).

See also http://gallica.bnf.fr/ark:/12148/bpt6k36420r.image.r=richelieu.fl29.langFR pagination, 86-89.

3 'Il faut remonter aux antiques révolutions de l'Orient, à ces nations vaincues qu'on traînait tout entières hors de leurs foyers, à la captivité de Babylone, pour trouver des spectacles semblables à celui que vit l'Europe du XVIIe siècle! La responsabilité de ce grand attentat 
This would be the overall tone of the few works published about the Moriscos, particularly in the nineteenth century.

Moving from fact to fiction with Cervantes, who knew the Moriscos well, we find in Part II of Don Quixote that Ricote says to Sancho, in a famous speech:

As I was saying, I left our village, went to France, and though they made us welcome there, I wanted to see everything. Itraveled to Italy, and came to Germany, and there it seemed to me I could live in greater freedom because the inhabitants don't worry about subtleties: each man lives as he chooses, because in most places there is freedom of conscience.

He goes on to speak of his plan to dig up his buried treasure and to find his wife and daughter "and find a way to take them to a French port, and from there to Germany." He concludes, "What amazes me is not knowing why my wife and daughter went to Barbary instead of France, where they could have lived as Christians."4

According to Philippe Berger,5 this chapter on the theme of the Expulsion would have been written around 1614 - that is, after Henry IV's death in 1610 and Marie de Medici's shift to a policy that advocated removing all the Moriscos from France.

What wasthereality of France's "welcome," and what doweknow about the Moriscos' ability to "live as Christians" there? We shall see that both assertions need to be qualified, like the claim about freedom of conscience in Germany.

Juan Goytisolo, in an opinion piece titled "Moriscos, la historia incómoda [Moriscos, an Inconvenient History]", remarks on the Ricote citation with these words: "Freedom of conscience! As an aside, and without emphasis, the

contrel'humanité porte exclusivement sur le catholicisme espagnol; lapapautérefusade s'y associer. Si implacable envers les ennemis domestiques, envers les hérétiques, elle n'avait pas le même acharnement contre l'ennemi du dehors, contre l'islamisme. La cour d'Espagne ne put obtenir que Paul V visât la sentence de proscription de tout un peuple": Henri Martin, Histoire de France depuislestempsreculésjusqu'en 1789, X(Paris:Furne), 1857, 560.

4 "Salí, como digo, de nuestro pueblo, entré en Francia, y aunque allí nos hacían buen acogimiento, quise verlo todo. Pasé a Italia y llegué a Alemania [...] [donde] cada uno vive como quiere porque en la mayor parte della se vive con libertad de conciencia"; "dar traza comotraerlas a algún puertode Francia, y desde allíllevarlas a Alemania"; "y loque me tiene admirado es no saber por qué se fue mi mujer y mi hija antes a Berbería que a Francia, adonde podía vivir como cristiana": Miguel de Cervantes, Don Quixote, trans. Edith Grossman (New York: HarperCollins), 2003, 813-814.

5 Philippe Berger, "Encore Cervantès et les morisques," in Siglos dorados. Homenaje a Agustín Redondo, vol. I (Madrid: Castalia), 2004, 120. 
author of Don Quixote here exposes the crux of the matter. The sentinels of the Holy Office were always on the alert, but a good reader would need no further words." 6 LuceLópez-Baralt, in discussing the picture that Cervantes paints of Ricote in the cited passage, thinks that "when Cervantes writes about the Spanish Moriscos, whom he knew intimately, he is usually not very far from historical truth."7 She is referring above all to his knowledge of the Moriscos' world and especially of its clandestine underworld. Roland Labarre, who dissents from Márquez Villanueva's (and, we might add, Goytisolo's)interpretation of Ricote's "freedom of conscience" phrase, believes that "to claim that it has the same positive meaning here that Protestants gave to it, and that it still connotes, requires ignoring its undoubted criticism of the lack of delicacy that is, of religious scruples - of the Germans; in any case we must accept that the intent of the phrase was pejorative, never forgetting that Cervantes was writing for the subjects of the Catholic Monarch."8

What, then, was the truth about that supposed freedom of conscience in Germany (in the United Provinces there was, in fact, a form of tolerance from the late sixteenth century onward), in the context of the confessionalisation 9 of theEuropeanmonarchies afterthePeace of Augsburg(1555)andespecially

6 “'iLibertaddeconciencia! Derefilón,y comoquiennoquiere lacosa,elautordelQuijotepone el dedo en la llaga. Los despiertos centinelas del Santo Oficio eran todo oídos pero a buen relector sobran más palabras": El País, 15 March 2009. See also Goytisolo's review of Francisco Márquez Villanueva's Moros, moriscosy turcos en Cervantes (Barcelona: Bellaterra), 2010, in “Cervantes y el mundo musulmán,” El País, 21 August 2010.

7 "Cuando Cervantes escribe sobre los moriscos españoles, que conoce tan de cerca, no suele estar lejos de la verdad histórica": Luce López-Baralt, La literatura secreta de los últimos musulmanes de Espaǔa (Madrid: Trotta), 2009, 396.

8 "Mantener que tendría aquí el sentido favorable que le atribuían los protestantes y le ha quedado hoy, supone por lo menos que no se haga caso de la alusión indudablemente crítica a la falta de delicadezas -o sea escrúpulos religiosos- en los alemanes, y, de todos modos, la evidencia de su significado peyorativo se impone por poco que no se olvide que Cervantes escribió para los súbditos del Rey Católico": Roland Labarre, "Tres antiparadojas sobre Cervantes,” Criticón 54 (1992), 113-121, esp.118-119. See Luis F. Bernabé Pons, "Cervantes y el islam: una revisión historiográfica," in Cervantes entre las dos orillas (Alicante: Universidad), 2006, 21-58, esp.47-58.

9 See Ignasi Fernández Terricabras, Felipe IIyel clero secular. La aplicación del Concilio de Trento (Madrid: Sociedad Estatal para la Conmemoración de los Centenarios de Felipe II y Carlos V), 2000, 373-380 (on the application of this concept to the Spanish situation); Ronald Po-Chia Hsia, "Disciplina social y catolicismo en la Europa de los siglos XVI y XVII," Manuscrits, 25 (2007), 29-43; Claire Gantet, "Le Saint-Empire," in L'Europe en conflits. Les affrontements religieux et la genèse de l'Europe moderne vers 1500-vers 1650 (Rennes: Presses Universitaires), 2008, 61-78; Christophe Duhamelle, "La 'confessionnalisation' en Allemagne," 
after the Council of Trent (1563)? We believe that we should adopt a nuanced view of the extent of tolerance and freedom of conscience in the sixteenth and early seventeenth centuries. As the work of Joseph Leclerc suggests, in the sixteenth century following the Peace of Augsburg, there was freedom of worship in Germany for sovereign rulers but not for their subjects: 10 the prevailing principle was cujus regio, ejus religio. The German Counter-Reformation was marked by intense literary activity in the politico-religious sphere, butfew works promoted tolerance (in the sense of concession or permissiveness in matters of religious liberty), and their influence was limited. Leclerc tells us that the mass of public opinion - whetherCatholic,Lutheran or Calvinist-did not accept religious diversity in the State. In this context the idea of an agreement among the three confessions did not prevail (except in Bohemia and Brandenburg, where local agreements were made), 11 and the Thirty Years' War (1618-1648) did not help matters. Wolfgang Kaiser maintains that confessional Europe, rather than opening a space for religious freedom or tolerance in the modern sense, created a restrictive framework 12 for Jews and Muslims. 13 As we caninferfrom thesestudies, Ricote's wife-whethershe was agood Catholic or not - would have found it hard to settle not only in Germany but even in France, as we shall see below. But first we should try to answer a number of questions that arise when we propose to write a "history" of the Moriscos in France. How many Moriscos passed through France? What were the conditions of their reception, by the authorities and by the local population? How many settled there, and how many merely traversed France on their way to North Africa or Turkey?

From today's perspective we can affirm that the Moriscos did not leave any significant traces in French historiography. Works on the Moriscos in France

in Des religions dans la ville. Ressort et stratégies de coexistence dans l'Europe des XVIe-XVIIIe siècles (Rennes: Presses Universitaires, 2010), 201-206.

10 Joseph Leclerc, Histoire de la tolérance au siècle de la Réforme (Paris: Aubier), 1955, I:257.

11 Ibid., 282 and 296.

12 Wolfgang Kaiser, "Sans issue?," in L'Europe en conflits, 427.

13 Ibid., 428. David do Paço, "Coexister dans la diversité religieuse des villes de l'Europe moderne, XVe-XVIIIe siècle," in Des religions dans la ville, op. cit., 14, describes this Europe of the sixteenth to the eighteenth centuries as "a tolerant Europe, that is a place where one tolerated the other for lack of an alternative; where one made the other pay for being what he was, whether by imposing a special tax or by physical violence" ("une Europe tolérante, c'est-à-dire où l'on souffrel'autre, à défaut de pouvoir faire autrement, dans laquelle on fait payer à cet autre ce qu'il est, que ce soit par le biais d'un impôt spécialou parcelui d'une violence physique"), although he insists that one must bearin mind the diversity of situations and contexts. 
are few: by Henri Lapeyre, 14 who provides data on the number of Moriscos who entered France; Bonifacio de Echegaray, 15 a member of the Basque language academy, who followed the footsteps of the Moriscos in the French Basque country; Louis Cardaillac, 16 who studied their passage through Languedoc; Osmin Ricau, 17 Robert Sauzet, 18 and Pierre Santoni19 for the MoriscosinProvence. These authors use the very few published sources on the topic, particularly Francisque Michel20 and Jules Mathorez,21 who rely in turn on the even fewer contemporary accounts of the events: the Mercure Français 22 (from 1605), the memoirs of the Duke of LaForce,23 Pierre Davity (1665),24 and a few local histories like those written about Marseille25 in the seventeenth

14 Henri Lapeyre, Géographie de l'Espagne morisque (Paris: SEvpen), 1959, 100-103, 152-153, 159-162, 186-187,251.

15 Bonifacio de Echegaray, "Se establecieron los moriscos en el País Vasco de Francia?," Bulletin Hispanique 47-1 (1945), 92-102.

16 Louis Cardaillac, Le passage des Morisques en Languedoc (Montpellier: Université Paul Valéry), 1970; ibid., "À propos du passage des Morisques par le Languedoc. Réflexion sur l'expulsion," in Questionnement des formes. Questionnement du sens (Montpellier:Éditions du cers - Université), 1997, 567-577.

17 Osmin Ricau, "L'Expulsion des Morisques espagnols en 1610: ses conséquences dans le Midi français," Pyrénées 103-104 (1975), 249-262 and 361-371.

18 Robert Sauzet, "Alonso López, procureur des Morisques Aragonais et agent de Richelieu (1582-1649)," in Actes du II Congrès International Chrétiens et musulmans à l'epoque de la Renaissance (Zaghouan: Fondation Temimi), 1997, 213-219.

19 Pierre Santoni, “Le passage des Morisques en Provence (1610-1613)," in Provence Historique 46-185 (1996), 366-367.

20 Francisque Michel, Histoire des races maudites de la France et de l'Espagne (Paris: A. Frank), 1847.

21 Jules Mathorez,Lesétrangersen Francesousl'Ancien Régime(Paris:Champion), 1919.

22 Online athttp://mercurefrancois.ehess.fr/.

23 La Force, Mémoires authentiques de Jacques Nompar de Caumont, Duc de La Force, vol. I (Paris: Charpentier), 1843.

24 D'Avity, Les estats, 145-148.

25 Antoine de Ruffi, Histoire de la ville de Marseille (Marseille: H. Martel), 1696, 454-455. [Online athttp://gallica.bnf.fr/ark:/12148/bpt6k1249419.r=ruffi.langFR]. These are the few lines on the passage of the Moriscos: "In the same year [1610] two Flemish vessels touched at the islands off Marseille, laden with a thousand Granadans, men, women and children; they had embarked at Seville by order of the king of Spain, who had expelled them from his kingdom. One of the ships foundered after its passengers disembarked. Most of them were lodged in old infirmaries, and since a few of them died every day, and it was feared that they might be dying of plague, it was decided to send them away. Several ships were hired to take them to Bône, Tabarka and other North African ports" ("En la même année [1610] deux vaisseaux flamans abordèrent aux isles de Marseille, chargés de mille 
century, and about the Pyrenees,26 Bayonne,27 Biarritz28 and Montpellier29 in the nineteenth. The value of these works resides in their recourse to a variety of archives - municipal, departmental, ecclesiastic and notarial - of the principal regions or cities involved: Saint Jean de Luz, Bayonne, Pau, Bordeaux,

Grenatins, tanthommes quefemmes etenfans, ilss'embarquèrentà Séville parcommandement du roi d'Espagnequiles avoit chassés de ses États un de ces vaisseaux fit naufrage après leur débarquement, ils furent logés la plûpart aux infirmeries vielles, et parce qu'il en mouroit tous les jours quelques-uns, et qu'on apréhendoit que cela ne causât la peste, on résolut de les congédier, on loua quelques navires qui les portèrent à Bonne, à Tabarque, et à d'autres ports de Barbarie").

26 V.Chausenque, LesPyrénées ou voyage pédestre danstouteslesregions deces montagnes, vol. I (Agen: Noubel), 1854, 72-73: "In traversing the sterile moorlands of Béarn and Guyenne one cannot forget that in 1610 the Moors, chased out of Spain, asked the king of France for permission to settle in those regions, but received nothing but the most impolitic of refusals. Without ports or fortified positions they could nothavebecomedangerous; and this wretched remnant of a people, at one time the most enlightened in Europe, who had dug canals, opened roads, dredged lakes, drained marshes, stabilised dunes and transformed sand into fertile fields, would have guaranteed the fertility of a vast swath of land that is now practically a desert. Ourenemy Africa received this rejected people, with their courage, their capital and their industry" ("En parcourant les landes stériles du Béarn et de la Guienne, on ne peut oublier qu'en 1610 les Maures, chassés d'Espagne demandèrent au roi de France d'habiter ces landes et qu'ils n'éprouvèrent que le plus impolitique des refus. Sans ports, sans positions militaires ils n'eussent pu devenir dangereux; etces malheureux débris d'un peuple, quifutun temps lepluséclairédel'Europe, en creusant des canaux, ouvrant des routes, évacuant les lacs, desséchants les marais, fixant les dunes, et changeant à la longue des sables en terres fertiles, eussent assuré la fertilité d'une vaste étendue de pays, qui est resté presque désert. Ainsi repoussé, l'Afrique ennemie les reçut avec leur courage, leurs capitaux et leur industrie").

27 V. Dubarat and P. Haristoy, Études historiques et religieuses du Diocèse de Bayonne (Pau: Vignancour), 1897, 520. On the Moriscos, this work offers only a document of 1610 that deals with their transit through the area:

"Expulsion of the Moriscos of Spain (1610). In this same year the king of Spain emptied hiskingdoms of Valenciaand Aranoa [sic: Aragón?] of all the Moriscos, aboutseventy thousand households in number; they were to cross into France, some at one place, some at another, especially through Navarre under the direction of the Sieur de Gramont, governor of Bayonne; others through the Ossau or Aspa Valleys, both young andold. And thesaid young ones, justliketheold, paidXV reials of passageapiece, the strong paying for the weak, beside several abusive hidden costs [?; estremis couvertes] which one and all render, together with the fees for tolls, border crossings and the foreigners' tax [forana] that they are required to pay and change their coins with the money-changers of the present land of Béarn, even though the said Moriscos do not know or understand the rate of exchange. The Moriscos hold to the damnable Mohammedan sect and hope to go on to Algiers, where people live under that same Mohammedan error and sect. 
Toulouse, Aix-en-Provence, Agde, Marseille and other small communities through which the Moriscos passed after their exile from Spain.

Today the Internet gives us access to a great many digitalized documents from the sixteenth and seventeenth centuries (e.g., certificates of baptism, marriage and death) from the departmental archives of Les Landes, Gironde, Bouches duRhône, and Hérault,30although it may be difficult toexploit these in search of Moriscos. Santoni draws attention to a series of important sources that would be worth exploring: the Parliament of Aix, and notarial collections in Aix, Arles and Toulon.31

Francisque Michel, Cardaillac and Santoni are the scholars who have contributed the most to the study of this minority group in France, presenting research questions and provisional conclusions that overlap and, though they are not definitive, form a necessary starting point for developing a history of the Moriscos in France. That history's duration was brief: some 40 years, if we begin with the first contacts with French authorities in the 1580s, when the Moriscos were trying to persuade them to invade Spain, up to the time when these Spaniards vanish from the documentary record. (We do not count here

"In the sameyear 1610 the king of Spain caused all the Moriscos to beexpelled from his lands, and many troops of them passed through this Aspa Valley in the months of July, August and September, heading for Toulouse and Marseille" ("Expulsion des Morisques en Espagne [1610] Lo medix an, lo rey d'España fe boeytar sons rejaumes de Balentia et Aranoa totz los Moriscos en nombre de septante mille casadas ou envyron qui s'en passan en France, los ungs per ung quartier, los autres per autre, notament per Navarre,jusl'appuy deu srdeGramont, gobernurdeBayona; autresperlabald'Ossau et autres per aqueste val d'Aspa, los totz petitz et grans; et losd. petitz, comme los grans,paganXVreyausdepassagechacunetlofortperlofeble, oultreplusorsestremis couvertes [?] que ungs et aultres los fen ransson, ensemps los dretz de peage, port et forana qui son constretz pagar et cambiar lors monedas aus mestes rendadors de las monedas deu present pays de Bearn, nonobstant que losd. Moriscos ignorassan tals cambys et cessassan entender tals cambys. Losd. Moriscos thienen la ley damnable : Mahomycaet aspiran se anar en Urgel ou Argel [Alger], ond viven en semblable secta et error Mahomica.

"Lo medix an 1610, lo rey d'Espanha fe boeytar totz los Moriscos de sas terras et forssa troppas en passan per aqueste vallee d'Aspa aus mes de julhet, aoust et septembre, tyrantz a Tholose et à Marseille"): Arch. comm. de Borse, bb 1, f. 15v.

28 L. André, ed., De Biarritz en Espagne. Aperçus pittoresques et historiques (Bayonne: L. André), 1864,61-70.

29 Charles d'Aigrefeuille, Histoire de la ville de Montpellier depuis son origine jusqu'à notre temps (Montpellier: C. Coulet), 1877, book XVII, 29-30; book XVIII, 38-39.

30 Departmental archives online: http://www.guide-genealogie.com/guide/internet.html\# archives.

31 Santoni, "Le passage,"336. 
the many Moriscos who entered France in the sixteenth century only to leave it on their way to the Ottoman Empire, the Maghreb or Mecca.) But such a history can be written for some French cities or regions, particularly in the south. The history in France of Moriscos, particularly Aragonese and Andalusians, who were cast out of Spain unfolded in the short interval between 1610 and 1614 , the years when they appear repeatedly in the documents. Most of them would have left France, or been expelled from it in turn, between 1610 and 1611. After the latter date they are recorded sporadically until the 1630s, perhaps representing the tip of an iceberg whose size we are now unable to calculate.

The geographic location of this minority group would be concentrated south of a line drawn from Bordeaux and its environs (Francisque Michel speaks of traces of Moors or Moriscosinthe Department of Charente, between Bordeaux and Angoulême32) to Cannes. But they may well have had a presence in cities to the north of the Dordogne (Paris, Rouen), or have been living in those areas even before the Expulsion.

Morisco contacts with France in search of support for a military invasion of Spain had begun in 1587 and continued up to 1608. In the words of Bishop Hardouin de Péréfixe of Rodez (in the Midi-Pyrenees), "Now [the Moriscos] having returned in this year of 1608 to beg [King Henry IV] to accept their proposals and offers at once $[. .$.$] : he gave them to understand very clearly that$ his position as Most Christian King did not permit him to take up their defense so long as the Peace of Vervins remained in force."33 This treaty, signed in May 1598 between Philip II and Henry IV, had ended the war between Spain and France and left the Netherlands in the hands of Isabel Clara Eugenia, PhilipII's daughter and wife to the Archduke Albert. TheFrench monarch was constrained to respect it, but if the Spaniards did not, il auroit juste sujet de les recevoir sous sa protection [he would have just cause to receive them (the Moriscos) under his protection]. The Moriscos ultimately appealed to the king of England, who proved just as deaf to their requests.34

32 Michel, Histoire des races, II: 318.

33 "Or estant revenus en cette année mil six cens huit pour le soliciter [Enrique IV] instamment d'accepter leurs propositions et leurs offres [...]: il leur fit entendre nettement que la qualité de Roy Tres-Chrestien qu'il portoit, ne luy permettoit pas de prendre leur défense, tandis que la Paix de Vervin subsisteroit”: Péréfixe de Beaumont, Histoire du roy Henry le Grand (Amsterdam: Elzevier), 1661, 441-442.

34 Proof of contacts between Moriscos and theEnglish is found in Luis CabreradeCórdoba, Relaciones de las cosas sucedidas en la corte de Espaǔa, desde 1599 hasta 1614 (Madrid: J. Martín Alegría), 1857, 240: [16 April 1605] “In Valencia many Moriscos have been imprisoned on account of certain letters sent by the King of England, found among the papers 
According to Péréfixe there were a million Moriscos in Spain, of whom some 150,000 had passed through Saint Jean de Luz, while others had arrived by sea at various French ports. The bishop is critical of the Spanish, but also of the French for the poor reception that they gave the exiles: "but to tell the truth, those who arrived by land were hardly better treated by the French than the others had been by the Spanish: for while crossing Les Landes they were almost all robbed, and their wives and daughters raped; so that, finding solittle security in a country where they had hoped to take refuge, they embarked with the King's permission from the ports of Languedoc and crossed to Africa." 35 Some remained in Bordeaux and even farther to the northeast, in Rouen.

Sully, minister to Henry IV (1553-1610), summarises in his memoirs36 the negotiations that took place between Moriscos and French Protestants before Henry's accession to the throne in 1589. That monarch planned to make allies of the Moriscos, "those internal enemies, to be taken into account less because of their number than because of the lively resentment that they still felt by virtue of their oppression."The Moriscos hoped to mount a general revolt, financedentirely by themselves, with French militaryaid(they askedforageneral and officers to lead them); in exchange they requested asylum in France, promising to convert to Protestantism:

of the latequeen [ElizabethI]; these were written tohimby Moriscos whoaskedforhishelp if they should rebel, promising that they would allow him to sack the city if he arrived with his fleet. Many of them have been tortured in an attempt to discover the truth of the affair, and some will be punished as an example to the rest"("En Valencia se ha hecho prisión de muchos moriscos, y por ciertas cartas que el rey de Inglaterra ha enviado, las cuales se habíanhalladoentrelos papeles delareinapasada[IsabelI] quelehabían escritolosmoriscos pidiéndoles favor para levantarse, y que ellos daría orden de que pudiese saquear aquella ciudad, viniendo con su armada. Hase dado tormento a muchos de ellos para averiguar lo que pasaba en este negocio, y no dejaran de castigarse algunos para ejemplo de los demás"). There was also the probability of an alliance among Moriscos, Moroccans and English. See Julio Caro Baroja, Los moriscos del reino de Granada: ensayo de historia social (Madrid: Istmo), 1976, 224-225, and also Antonio Domínguez Ortiz and Bernard Vincent, Historia de losmoriscos. Viday tragedia de una minoría (Madrid: Alianza), 1997, 173-175.

35 "Mais à dire le vray ceux qui vinrent par terre ne furent gueres mieux traittez par les François, que les autres l'avoient ésté par les Espagnols: car en traversant les Landes, ils furent presque tous dévalisez, et leurs femmes et filles violées; de sorte que trouvant si peu de seureté dans un païs où ils croyoient trouver du refuge, ils s'embarquèrent par la permission du Roy aux ports de Languedoc, et traversèrent en Afrique.” Péréfixe de Beaumont, 1661,443.

36 Maximilien de Béthune, duc de Sully (1559-1641), Mémoire de Sully, principal ministre de Henri-le-grand (Paris: J.-F. Bastien), 1788, IV: 519-525. 
They appeared so well disposed toward religion that they offered toadopt that of our realm; not, in truth, the Roman religion, for the tyranny of the Inquisition had rendered that second servitude even more unbearable to them than the first, but the reformed Religion. They found that they could conform easily to a worship that was free of images and ceremonies (which they considered idolatrous), and in which almost the sole object was one God, worshipped and invoked equally by all.37

After the Spanish authorities uncovered the plot, the Moriscos appealed once more to the French king to request, this time, that he accept them as his subjects; but once again they received no positive reply. 38 Sully concludes by speaking of the number of Moriscos expelled from Spain, some 500,000,

37 "Ces ennemis domestiques, moins considérables encore par leur nombre, que par le vif ressentiment qu'on leur voyoit conserver de leur oppression"; "Ils paroissoient de si bonne composition sur la religion, qu'ils offroient d'embrasser celle du royaume; non pas, à la vérité, la religion Romaine, la tyrannie de l'inquisition leur avoit rendu cette seconde servitude encore plus insupportable que la première, mais la Religion réformée. Ils trouvoient qu'ils s'accommoderoient sans peine d'un culte dégagé des images et des cérémonies, qu'ils disoient sentir l'idolâtrie, et dont un seul Dieu également adoré et invoqué de tous, étoit presque l'unique objet": Ibid., 520-521. In another work, Les œconomies royales (1610), Sully alludes to the possible conversion of the Moriscos to Protestantism and the compatibility between the two religions, claiming that the Moriscos "would rather be prepared to embrace the belief of the reformed Christians, in which they knew that only one God was worshipped, prayed to and invoked; that there were no images among them, so that no idolatry was committed, for that is what they detested the most; and in which very few ceremonies were observed of the type that they could not assent to" ("se disposeroient d'embrasser plustost la créance des chrétiens reformes (en laquelle ils sçavoient qu'un seulDieu estoit adoré, priéet invoqué, qu'iln'y avoit pointd'images parmy eux, ne s'y commettoit aucune idolatrie, qui estoit ce qu'il détestoient le plus, et ne s'y observoit que fort peu de cérémonies ausquelles ils ne se résolussent de s'accommoder"): in Collection des mémoires relatifs à l'histoire de France. CEconomies royales, t. VIII (Paris: Foucault), 1821,328.

38 Ibid., 523: "Determined to do anything to throw off the Spanish yoke, they asked him to accept them as his subjects on any conditions that he wished. But the same motives that prevented His Majesty from taking the side of the United Provinces openly (in a situation that affected him much more closely) did not allow him to declare himself the liberator of a people who were even more subject to Spain. Further, he would have had to follow them into very distant places, and they were demanding armed vessels: for the center of the revolt was near the coasts of Valencia, Murcia and Granada. And there were several other reasons based on the character of that people, without mentioning the ordinary aspects of any affair that distance always hides, or disguises in part. Because of all this, surely no one could blame His Majesty for not having responded more positively to the 
according to him; in a footnote, the editor of the memoirs (J.-F. Bastien, 1788) makes aninteresting commentaboutHenry IV's position, giving one to understand that the same motives that had caused their expulsion stood in the way of their being welcomed.39

Louis Cardaillac pushes the first contacts between Moriscos andFrench Protestants back to 1575, when they sought, of necessity, allies for an invasion of Spain. He also alludes to conversions of Moriscos to Protestantism, citing a few trials from the archives of the Inquisition tribunal in Toledo. 40

Werner Thomas 41 cites similar contacts from 1574 onward, and offers interesting data about isolated cases of proselytising by Béarnais Protestants in Morisco villages in Aragón. He mentions the towns of Letux and Lagata (in the Campo de Belchite region), where the Béarnais Juan de Secas offered himself as a preacher in case the Lutherans should invade Spain.42

Both Cardaillac and Werner on the Moriscos, and Victor Segesvary on the broaderissue of relations between Islamandthe Reformation, 43 stressthe areas of agreement between the two belief systems (rejection of images, anti-Papism,

desires of the Moorish people" ("Détérminés à tout, pour secouer le joug espagnol, ils le prièrent de les prendre au nombre de ses sujets, àtelles conditions qu'il voudroit. Mais les mêmes considérations qui empêchoient sa Majesté de prendre ouvertement le parti des Provinces-Unies dans un intérêt qui le touchoit de beaucoup plus près, lui défendoit aussi de se déclarer le libérateur d'un peuple encore plus particulièrement sujet de l'Espagne, et qu'il falloit de plus chercher dans des lieux fort éloignés, et qui demandoient un armement de mer; car le centre de la révolte étoit du côté de Valence de Murcie et de Grenade sans compter plusieurs autres raisons tirées du caractère de ces peuples, et sans parler des incidens si ordinaires dans les affaires, que l'éloignement cache toujours, ou déguise en partie. Toutcelafaitqu'on ne sçauroit assurémentblâmer sa Majestéden'avoirpas mieux répondu aux désirs de la nation Maure").

39 Ibid., 525: "One might say that the same reason that caused the Moors to be cast out of Spain also prevented their being received in France. But it seems that it would have been easy to take advantage of their sad situation to make them do anything that one wished" ("On diraquela mêmeraison qui faisoit chasser les Maures del'Espagneempêchoit aussi qu'on ne les reçût en France. Mais il semble qu'il auroit été facile de profiter de la triste situation où ils se trouvoient, pour les amener à faire tout ce qu'on eût pu désirer d'eux").

40 "Morisques et protestants," in Morisques et chrétiens. Un affrontement polémique (1492-1640) (Paris: Klincksieck), 1977, 140-142.

41 Thomas Werner, "La complicidad entre protestantes, judíos y moros," in La represión del protestantismo en Espaǔa, 1517-1648 (Leuven: University), 2001, 103-110. See also by the same author Los protestantes y la Inquisición en Espaǔa en tiempos de la Reforma y Contrarreforma (Leuven: University), 2001, 364-366.

42 Werner, "La complicidad," 106.

43 Victor Segesvary, L'islam et la Réforme. Étude sur l'attitude des réformateurs zurichois envers l'islam (1510-1550) (Lausanne: L'Age d'homme), 1977. 
criticism of the Sacraments and of clerical abuses, etc.) but nonetheless insist that there was no doctrinal alliance and that the two groups' respective aims continued to be different. For Protestants, the first priority was to reform the Church; for Moriscos, to press Protestant arguments into service for their antiChristian polemics. We might speak of a sort of strategic sympathy, but in the end Mohammed, like the Pope, still represented the Antichrist for Protestants. There may have been some conversions - we do not know how many - but we can guess from the reaction of Protestant religious authorities that they did not believeMoriscoconversionstobesincere. Cardaillac offers the example of the Synod of Vitré in 1617 (not 1677),44 which resolved to take measures against abuses by the Moriscos and to control them better:

All Churches are warned to pay close attention to Moors expelled from Spain who move from Church to Church, so that they may not receive them too lightly and may vouch for them only after a close Examination of their Lives and Beliefs: and those who have already been received and have joined a Church should also be examined with care, both as to their level of instruction and especially as to their conduct. And when anyone witnesses in their favour he should mention their baptism and the number of their children, specifying also if the latter have been baptized and at what ages. And such certificates should mention by what signs one may know that these are the same persons. 45

In spite of everything, at the present state of research Cardaillac's conclusion remains valid: that the conversion of Moriscos to Protestantism was no more than a secondary phenomenon among the events of their exodus. 46

44 Cardaillac, Morisques et chrétiens, 145. 1677 is a typographic error, since the last national synod of the Reformed Church took place in 1659. Moreover Cardaillac notes correctly on the following page that the minutes of synods held after 1617 make no reference to Moriscos.

45 "Toutes les Eglises sont averties de prendre soigneusement garde sur les Maures chassés d'Espagne, etcouransd'EgliseenEglise, pournelesrecevoirpas troplégèrement, etonne leur donnera aucune attestation qu' après un bon Examen de leur Vie et Croiance: et ceux qui sont déjà reçus et demeurent dans quelque Eglise, seront aussi soigneusement examinés, tant pour ce qui concerne leur instruction que sur toute leur conduite, et quand on leur donnera des témoignages, on y fera mention de leur ba[p]tême, et du Nombre de leurs enfans, en spécifiant aussi s'ils ont été ba[p]tisés, et à quel âge, et par quelles marques on pourra reconnoitre que ce sont les mêmes personnes, dont il sera fait mention dans lesdits certificats": Aymon, Tous les synodes nationaux des Eglises réformées de France (Hague: Charles Delo), 1710, II: 96-97. [Online at www.gallica.fr].

Cardaillac, Morisques et chrétiens, 146. 
Other documents further illustrate these French contacts with Moriscos and the possibility of an alliance with themagainst Spain. In 1602 the Moriscos of Segorbe 47 sent a petition to King Henry IV in which they proposed a united front of Spanish Moriscos, Jews and Lutherans who were prepared to revolt: "and other peoples who are in Spain, some of the Religion of Christ and others of the Law of Moses, will line up on the side of France; they are many, although they live in hiding; we know them well and we offer consolation to each other...."48 This scheme may explain the warm welcome that the Moriscos received when they crossed the French frontier between January and 15 April 1610. On the latter date a new, more severe order was issued that annulled the earlierone of $22 \mathrm{February}$. That one had been very favourable to Moriscos who professed Catholicism: they were allowed to settle to the north of the Garonne and Dordogne Rivers (the authorities were wary of having them too close to the Spanish border), while any others had to leave the country via the Mediterranean ports. The quotation from Ricote (see above) must have referred to this period of time, because the decree of 15 April forbade entry to any more Moriscos and made clear that none could remain in France no matter how sincere they appeared in their Christianity: "to force those who are there to leave and cross to Barbary."49 Even before Henry IV's death on 14 May 1610 the policy toward the Moriscos had changed, and things would not improve under the regent Marie de Medici.

The Parliament of Toulouse (June 1610), the Parliament of Provence (December 1610), and the cities of Bordeaux (1611,1612 and 1613) and Marseille would take similar measures designed to expel all the Moriscos, in an atmosphere that had grown tense through fear of epidemics and through the difficulties of harbouring so many individuals (with the consequent begging, looting, manifest signs of Muslim identity, etc.). For instance, the Parliament of Provence on 4 December 1610 took steps to banish Moriscos living in the region because "the great majority are Mohammedans, and such a race of people should not live among Christians."50

47 La Force, Mémoires, I: 345.

48 'Etd'autres nations qu'ily a en Espagne, qui sont de la Religion du Christet d'autres dela Loi de Moïse, se rangeront du parti de la France, et ceux-ci sont nombreux quoiqu'ils vivent fort cachés; nous les connoissons bien, et nous nous consolons les uns les autres...": “Mémoire adresséà Henri IV par les Morisques d'Espagne," in Henri Baraude, Lopez, agent financier et confident de Richelieu (Paris: Revue Mondiale), 1933, 183-188.

49 "Pourceux qui y sont de les faire sortir et passeren Barbarye”: Ricau, "L'Expulsion," 259.

50 "La plus grande partie sont maumétistes, que telle race de gens ne doivent habiter parmi les chrétiens": Michel, Histoire des races, 86. 
How to explain the change? This was a situation similar to that of the previous year, 1609, when the Moriscos of Valencia were sent to Oran: Mikel deEpalza has called this operation, which had been very well organised at the Peninsular end, a chapuza [botched affair].51 Osmin Ricau speaks of the "criminal casualness and lack of foresight of Cardinal [sic] Lerma and King Philip III in casting onto the roads these crowds of unfortunate fugitives [...] without the least regard for their fate in a foreign land, especially after the shock of an incursion so numerous that it would entirely overwhelm the capacities of reception and victualling of the invaded provinces." 52 In the absence of any agreement by the local authorities, who had made no preparations at all, the impoverished local Berber inhabitants - who were already suffering through a severe drought - acted aggressively toward the newcomers.

When the Moriscos entered France the Spanish authorities were equally careless, but French officials allowed entry at first because they were taken by surprise (17,000 Granadans crossed between February and April 1610); they closed the frontier temporarily in June 1610, requiring some 14,000 Moriscos to return to Los Alfaques, and then reopened it in September 1610 so as to avoid even worse consequences.53 Local populations reacted badly for the same

$51 \quad$ MikeldeEpalza, “Losmoriscosysusdescendientes, despuésdelaexpulsión(despuésdel cuadro del desembarco en Orán), " in La expulsión de los moriscos (Valencia: Bancaja), 1998, 43-70.

52 "[La] légèreté et imprévoyance criminelles du cardinal de Lerma et du roi Philippe III jetant sur les chemins des foules de malheureux fugitifs [...] sans se préoccuper nullement de leur destin en pays étranger, surtout dans la surprise d'une irruption si nombreuse qu' elle allait dépasser grandment les capacités d'accueil et de nourriture des provinces envahies": Ricau, “L'Expulsion,” 262.

53 Cabrera, Relaciones, 410 (3 July 1610): "The Moriscos have begun to be removed from Aragón and given permission to traveloverland toFrance; some 14,000 of them arrived at the border crossing at Canfranc, where they learned that the Queen of France had proclaimed that no Morisco would enter her realm, on pain of death; for they were in great need, and she did not want her kingdom overrun with beggars and paupers. This happened after some towns had already expended more than 40,000 ducados for permission to enter France, in addition to the tariffs they had paid on their belongings at the borders, and fees to the officers. Then they had to turn back to Los Alfaques to board ship for Barbary, which is a long journey; and on descending the mountains they began to take sick and die, and it was feared that with the heat of summer some plague would arise in the galleys and ships, if great haste were not made to embark them and take them away" ("Hánse comenzado á sacar los moriscos de Aragón, y darles permisión que puedan pasar por tierra á Francia, de los cuales han venido como 14,000 al puerto de Canfranc, donde supieron que la Reina de Francia había hecho pregonar que ningún morisco 
reasons as the natives of Oran: drought, lack of food for somanyexiles, feelings of insecurity (accompanied by many complaints about the behaviour of the Granadans), fear of epidemics, and rejection of the Moriscos' religious practices. 54

Documentary sources contain instances of abuse by ordinary French people, by ships' captains and sailors who were in charge of transport, and by some officials like Pierre d'Augier, who was responsible for embarking the Moriscos at Perpignan. But the Moriscos had the option of denouncing those abuses, so that a number of lawsuits were brought and the French authorities imposed severe sanctions, including even the death penalty, on the guilty.

French historians of the time and in the nineteenth century estimated the number of expelled Moriscos at between 400,00055 and one million; the Mercure François, for instance, spoke of 900,000. A translation of the Expulsion decree of 12 January 1610 against the Moriscos of Andalusia, Castile and Murcia, published in Paris by François du Carroy's press in 1611, bears on its cover the

entrase en su reino, so pena de la vida, porque iban muy necesitados, y no quería dar lugar se hiciese su reino de mendigos y pobres, lo cual les sucedió después de haber pagado algunos lugares por la licencia para ir á Francia mas de 40,000 ducados, y lo que habían pagado de derechos en los puertos de lo que llevaban, y álos comisarios que los guiaban; y así habían de dar la vuelta á los Alfaques para embarcarse para Berbería, que hay buena travesía; y al bajar de la montaña comenzaban a enfermar y morir, y podía temerse con los grandes calores no se encendiese alguna peste en las galeras y navíos, sino se pone grande diligencia en embarcarlos y llevarlos").

54 D'Avity, Les estats, 146: "To hasten the passage of the said Moriscos to Barbary, on account of the complaint made by the inhabitants of Provence and Languedoc about the inconvenience of the Moriscos' presence, and the danger of contagion through the poverty to which they were reduced (the hospitals of Marseille being full of them); Their Majesties, as I said, sent in response the Sieur d'Aymar, charging him with ridding those lands entirely of Moriscos and seeing that they were escorted and sent to Barbary; not allowing any harm or injury to be done to them, and making sure that everything be done to calm the natives of the said Provinces" ("Pour faire haster le passage desdits Morisques en Barbarie, à cause de la plainte que faisoient les habitans de Provence, et du Languedoc, touchans l'incommodité du séjour desdits Morisques, et le danger de contagion par la misère où estoient réduits plusieurs d'iceux Morisques, dont les Hospitaux de Marseille estoient remplis: leurs Majestez, dis-je, envoyèrent le sieur d'Aymar des requestes, avec commission de délivrer entièrement lesdits païs de tant de Morisques et les faire conduire et passer en Barbarie, sans qu'il leur fust faict aucun tort ny iniure, et regarder à ce que le tout se fist au repos des habitans desdites Provinces").

55 Fernand Mourret, Histoire générale de l'Église. L'ancien régime (XVIIe et XVIIIe siècles) (Paris: Bloud et Gay), 1928-1933, 73. 
figure of over 900,000 expelled.56 We have seen that Richelieu believed them to number about 800,000. For Francisque Michel they totaled one million, of whom $15 \%$ or about 150,000 would have passed through France. E. Castelot puts the figure at about 500,000.57

It was only with the studies of Lapeyre, Cardaillac and Santoni that more realistic numbers would be offered: according to these writers, between 50,000 and 60,000 Moriscos would have traversed France, that is to say, between $15 \%$ and $20 \%$ of all those expelled. These figures approximate those proposed by d'Augier,58 the officer in charge of embarking the Moriscos in Provence. We cannot know with certainty how many stayed in France: perhaps the Catalans - some 3000 -, some rich Sevillian families and the occasional adventurer.

\section{The Jealous Granadan, the Transvestite Morisco and the Chameleon}

Because, as we have noted, the history of the Moriscos in France was very short - some 40 non-continuous years, from the first contacts in the 1580s up to the 1630s - and left few traces in the documentary record, we may choose to follow the footsteps of a few individuals who had prominence or attracted our attention because they were singled out in a particular source.

Gregorio Marañón59 offers a list of Moriscos who remained in France and might have had some socio-economic relevance: the wealthy Juan Burra, of Huesca, in Toulouse; Lope Alexandre and Baltasar Barbastro. In Marseille he

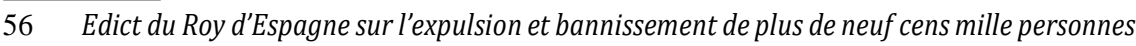
Morisques de son Royaume, qui machinoient de mettre l'Espagne entre les mains et en la puissance des Turcs et Sarrazins (Paris: F. du Carroy), 1611.

57 E. Castelot, "L'expulsion des morisques d'Espagne," Journal des économistes 7-4 (1904), 17.

58 Santoni, "Le passage," 355-356. Francisque Michel, describing the Morisco Alfonso López's suit against d'Augier, writes that "he also produced certificates showing that he had conveyed and caused to be conveyed 60,000 Moriscos in safety across Languedoc, and that he had seen them embarked at the port of Agde with great care and foresight and carried to Barbary, with their belongings and in total safety" ("il produit aussi quelques certificats portant qu'il avait conduit et fait conduire en sûreté à travers le Languedoc, soixante mille Morisques, qu'il les avait fait débarquer au port d'Agde avec beaucoup de soin et de prévoyance et transporter en Barbarie, avec leurs biens, en toute sûreté”): Michel, Histoire des races, 84.

59 Gregorio Marañón, Expulsión y diáspora de los moriscos espaǔoles (Madrid: Santillana, Fundación Gregorio Marañón), 2004, 79-80. 
claims the presence of "cientos deellos muyricos [hundredsof veryrichones]" like Manuel Granada deÉpilafrom Aragón, AlonsoMuley and acertain Fierro from Lérida. Santoni cites other wealthy Moriscos who certainly stayed in France, and who played an important role as intermediaries between the French authorities and Moriscos who were crossing the border: Diego de Cárdenas and Jerónimo Enriquez in Marseille.60

We would like to highlight here the stories of three Moriscos, two of them anecdotes that bear retelling, and the third as fascinating as a novel.

Charles d'Aigrefeuille devotes just a few paragraphs of his Histoire de Montpellier to the Moriscos' transit through Languedoc,61 informing us indirectly of the presence of Moriscos in Montpellier before and after their passage and Expulsion. In Book XVIII, Chapter 1, he tells the story of a Morisco gardener from Granada who had taken refuge in Lunel (about $21 \mathrm{~km}$. to the southwest of Montpellier) and who played a leading role in an event that aroused the whole region in 1614.

This gardener, who was 45 years old and lived in a small house in the village, took in one day another Morisco from Granada who, passing through with his wife and son, had asked for shelter. The host was glad to oblige, for "he developed from the first a violent passion for his guest's wife." In the course of the stay the wife rejected his determined advances on several occasions, until in his frustration the gardener conceived the dastardly plan of eliminating the husband, "the only check on his desires." Inviting him out into the fields, he murderedhim ("he killed him with knife-blows andhid him as well as he could in a ditch"). On the host's returning home, the son questioned him about the bloodstains on his shirt; our Moriscoended by confessing his crime, but threatened the son with the same fate if he told anyone about it.

The wife, concerned about her husband's absence, asked where he was, to which our Morisco replied that "he had gone to Montpellier to see other members of his nation." The host continued to harass the wife and, in the face of her continued rejection, confessed his crime to her; he begged her to marry him and ended by forcing himself upon her ("and whether willingly or by force, he made her submit to his passion"). Then he petitioned a judge in Lunel to let him marry her, since her husband had disappeared. The judge agreed, but as the couple were on their way to church a man appeared who was wearing the dead man's clothes; asked how he had got them, he claimed to have bought

$60 \quad$ Santoni, "Le passage," 365-368.

61 Charles d'Aigrefeuille, Histoire de la ville de Montpellier depuis son origine jusqu'à notre temps [1737], (Montpellier: C. Coulet), 1875-1882, 38-39; 29-30 relate the passage of the Moriscos. 
them from some shepherds who had found a dead body in the fields. Witnesses remembered having seen that same clothing on the woman's first husband. In the ensuing alarm, the judge suspended the wedding and transferred the case to the criminal court in Montpellier.

Arrested and imprisoned, the host continued to deny his crime until, under torture, heconfessed and was executed in April 1614 ("but the pain of the questioning to which he was subjected caused him to tell the truth at last: and he was condemned to die on the wheel in the City Hall square, the sentence being carried out in the month of April 1614").62

This episode, to which the author devotes the same number of pages as to the Moriscos' passage through the region, gives usindirectly someinteresting information about the fate of the group in France. The year 1614 fell after the decree that required Moriscos to leave the country, and after local authorities had adopted many measures to expel them (with a few exceptions for those who professed the Christian faith before Church authorities). Yet there were still Moriscos residing in Montpellier and its environs: the text says about the murdered husband that "he had gone to Montpellier to see other members of hisnation." Ourprotagonistseemstohave "professed" the Catholicfaith, since afterobtaining the judge's permission he was preparing to marry in the Church. We do not know when he had arrived in Lunel, but he must have been there since the early Expulsion years: the text speaks of him as an exile ("this man, a refugee in Lunel, cultivated agarden there"), and all we know of him is what he himself stated at his trial, that he was "a man of forty-five [...] who had seen [...] so many things and had experienced many changes of fortune."63

The Mercure François, 64 an ancestor of our modern press and one of the main sources of contemporary information about the Moriscos in France, offers anotherinteresting story that illustrates their presence there even before the Expulsion.

An issue of the Mercure for 1613 begins with a series of outlandish stories (about the giant Theutobochus whose bones, "discovered" by charlatans to

62 "Il conçut dès lors une violente passion pour la femme de son hôte"; "le seul obstacleàses désirs"; "illetüeàcoups de couteau etlecachelemieuxqu'il peutdansunefosse"; "ilétoit allé à Montpellier voir quelques-uns de sa nation"; "et de gré ou de force il la fit consentir à sa passion"; mais les douleurs de la question, où il fut appliqué l'obligèrent enfin d'avoüer la vérité; et il fut condamnéà mourir surunerouë, dans la place del'Hôtel-de-Ville: cequi fut exécuté au mois d'avril 1614."

63 "Cethomme,réfugiéà Lunel,y cultivoitunjardin"; “un hommedequarante-cinqans [...] qui avoit vû [...] tant de choses e éprouvé l'une et l'autre fortune."

64 Jean Richer, ed., Le Mercure François (Paris: J. Richer) 1613, 1613 III: 274. 
perpetrate a fraud, proved to be non-human fossils; about another deceiver who claimed to be a hermaphrodite but was unmasked through the intervention of the famous anatomist Jean Riolan, junior). The publication then relates that there was a twenty-five-year-old Morisca hermaphrodite living in Paris under the name of Marion Manuel.65 In view of the public scandal, that same Riolan and several other physicians from Paris's faculty of medicine tried to examine her, but as she resisted, they called on the authorities to intervene. We learn from the interrogation after her arrest that she had lived in Paris for ten years (i.e., since 1603) as a servant: elle servoit deux Demoiselles logées ensemble [she served two young Ladies who lived together].

The medical examination yielded a firm result: Marion was not only not a hermaphrodite, but was only pretending to be a woman.66The doctors discovered an uncircumcised member. Its owner was imprisoned and obliged to assume man'sclothing etlegarder tousiourssurpeinedela vie [and to wear it always, on penalty of death]. There is no reference to whether he was banished.

Aside from the morbid fascination of this sort of anecdote, we must admit that the story of a transvestite Morisco is an interesting one. We do not know, and perhaps will never know, how and why a young man of fifteen arrived in Paris before the Expulsion decrees and lived there for ten years disguised as a woman, at a time when such behaviour usually brought the death sentence. But we have here a perfect illustration of the different strategies that Moriscos adopted in order to survive.

Another more prominent personage, the Aragonese Morisco Alfonso López, 67 does provide us with solid information about the strategies that he

65 Ibid., 274: "There was a Morisca aged twenty-five years, with well-formed [traits of] both sexes, which sheemployed; sheused togoaboutParisdressed as agirl, recognizedbyeveryone as a Hermaphrodite, and little children would point at her and call her by that name."

66 Mercure François, III:275: "but the wily 'Morisca,' using hiscraft, withdrew his testiclesinto his groin and hid them together with his penis behind crossed hands: and with his fingers (the thumb and index finger of each hand) made his scrotum into the form of a vulva or cleft..."(“mais la moresque rusée, usant de son artifice, retira ses testicules dansles aines, et les cachoit avec sa verge dans le creux de ses mains: et de ses doigts, [qui sont le poulçe etl'indicatifdechaquemain] figuroitsesbourçesenfaçon devulve, oufente....'Thedoctors discovered the trick, and "perceived his virile member, which was of a thickness and length corresponding to his age, while his hanging testicles were the size of hen's eggs" ("apperçeurent son membre viril prominent avec une grosseur et longueur competente à l'aage, et ses testicules pendants gros comme des œufs de poulle”).

67 See Youssef El Alaoui and Luis F. Bernabé Pons, "Sur les traces d'Alfonso Lopez, créature morisque de Richelieu," in L'expulsion des Morisques. Quand? Pourquoi? Comment?, 
developed in his adopted country of France. This fascinating individual lived from the sixteenth to the seventeenth centuries, so that we can view through the lens of his experience the reigns of Philip III and his valido[favourite] Lerma, Philip IV and his favourite, Olivares, the France of Henry IV and his minister Concini, that of Louis XIII and Richelieu, and even the first years of the reign of Louis XIV and Mazarin.

Our protagonist moved within an atmosphere of political and military antagonism between Spain and France, against a background of acute Hispanophobia during his first years in France during the reign of Henry IV;68 under Richelieu this fear became more discreet, if not less hostile. Hispanophobia in France was mirrored by Francophobia in Spain. These tensions can be explained by France's longstanding opposition to the Hapsburgs and by Spain's position as the dominant superpower in Europe. Because of Spain's military, economic and financial power, claims Joseph Pérez, it "is sometimes admired; more often it is feared; it is criticised; its arrogance, its excesses, its crimes are denounced. Why is Spain reproached? Because of its will to power and its desire to dictate the law to the rest of Europe."69 This image of Spain arose from international circumstances and was not truly

international congress organized by Bernard Vincent(eHESs), 2-3 July 2009, Colegiode España, Paris [inpress].

68 Afine example is a work by Antoine Arnaud (1560-1619),Coppie del'Anti-espagnol,faictà Paris. Deffendu par les rebelles de Sa Maiesté par Ant. Arnauld (Lyon: P. Ferdelat), 1594, 12-14: after attacking the cruelty of Spanish bouchers [butchers] in the Indies, he predicts that the French will never let themselves be ruled by these Maranes [swine], i.e., Marranos), half Moors and half Jews: "What, are these Swine to be our Kings, our Princes? ShallaFrenchgentlemanbow the kneeby aSpaniard'scommand? ShallFrancebecaught in the snares of this King of Majorca, this half-Moor, half-Jew, half-Sarracen? [...] Oh, rather let the earth split open, let the sea overflow its bounds, we shall die without being able to command otherwise [...]" ("Quoy? que ces Maranes soyent noz Roys! noz Princes! queleGentil-hommeFrançoisfléchisse souzlecommandementEspagnol?quelaFrance soit adioustée entre les filtres de ce Roy de Maiorque, de ce demi More, demi Juif, demi Sarrazin? [...] O que plustost la terre s'ouvre, que la mer rompe ses rempars, nous mourrons sans y pouvoir donner ordre [...]").

69 “On admire parfois l'Espagne; plus souvent on la craint; on la critique; on dénonce son arrogance, ses excès, sescrimes. Quereproche-t-onàl'Espagne? Sa volontédepuissance et sa prétention à dicter la loi à l'Europe": Joseph Pérez, "Les rapports culturels entre la France et l'Espagne (XVI-XVII siècle)," in Les Monarchies française et espagnole du milieu du XVIe siècle à 1714 (Paris: Editions du Temps), 2000, 314. See "Francophobie et hispanophobie" in Alain Hugon, Au service du roi catholique. "Honorables ambassadeurs" et "divins espions." Représentation diplomatique et service secret dans les relations hispano-françaises de 1598 à 1635 (Madrid: Casa de Velázquez), 2004, 54-63. 
universal, since detestation of its power was combined with cultural attraction and a certain ambiguous admiration.70

This ambiguity is reflected in a work by a converso [Jewish convert] doctor and friend of our Alfonso López, Dr. Carlos García: La oposicióny conjunción de losdosgrandesluminares delatierra.Obra apacibleycuriosa enlacualsetrata de la dichosa Alianza de Franciay Espaǔa. Con la Antipathía entre Espaǔolesy Franceses [Opposition and Conjunction of the Two Great Luminaries of the Earth. A Pleasant and Curious Work on the Fortunate Alliance of France and Spain. With the Antipathy Between the Spanish and the French] (Paris, 1617), better known under its short title Antipatía entre espaǔoles y franceses. It was written to celebrate the imminent reconciliation of the two powers through the marriage of the future Louis XIII to the Spanish infanta Anne of Austria in 1615. Carlos García recalls in the work the historical reasons for the two nations' discord and mutual antipathy, andends by praising the rapprochement that the marriage would bring; yet the text was employed afterward rather as a proof that the twonations were irreconcilable. For Pelorson, García's testimony was the most direct and concrete evidence of the continued Hispanophobia suffered by the Hispano-Portuguese community in Paris in 1617.71

To understand our Alfonso López we must be aware of the atmosphere of hostility and rejection toward Moriscos in Spain, and of xenophobia toward Spaniards in France. Another important element was the context of the Spanish exiles in Paris. This was both political - in the circle that surrounded Philip II's secretary Antonio Pérez (1591-1611), a circle that Alfonso López frequented in Paris - and religious: Paris housed a community of Spanish and Portuguese conversos in which Alfonso López had close and deep contacts and even friends. Healsokeptcompany with some Moriscos(employees of his, for example) whom historians have not identified.

Allof thesegroups were marked by ambiguityin theirloyalty toSpain: some felt resentment or hatred of their native country, while others dreamed of returning to it one day. Therefore it would be more accurate to call them antiHapsburg rather than anti-Spanish. Their nostalgia for Spain would lead them

$70 \quad$ Henry Méchoulan, “L'Espagne dans le miroir des textes français," in L'État baroque. Regardssurlapensée politiquedela France du premierXVIIe siècle(Paris: Vrin), 1985, 424 ff. Forexamples of Francophobiain Spanish texts see Asensio Gutiérrez, La Franceetles Français dans la littérature espagnole. Un aspect de la xénophobie en Espagne (1598-1665) (Saint-Etienne: Université), 1977: Chapter 2 deals with relations between Spaniards and French immigrants, and with the negative image of the latter in Spain ("Activité des Français en Espagne,"45-92).

71 Jean-MarcPelorson, "Le docteurCarlos García et la coloniehispano-portugaise de Paris (1613-1619),” Bulletin Hispanique 71 (1969), 518-574. 
to work as informers or spies for both sides, in the hope of a future return. John Elliott and Alain Hugon believe that Alfonso López was a double agent,72 although at present nothing in his history allows us to confirm the fact. Had he been one, in any case, it could only have been with Richelieu's approval, for López was entirely the Cardinal's creature.

There are few studies dedicated to Alfonso López: the best documented is still Henri Baraude's Lopez, agent financier et confident de Richelieu.73 Julio Caro Baroja dedicates a chapter to him with the title "El último abencerraje."74 An article by Françoise Hildesheimer 75 and another by Sauzet 76 complete the picture. A number of studies give him a few lines or, at best, a page or two;77 but these repeat, even reproducing the same errors, the work of Henri Baraude and the sources he drew on (e.g., Tallemant des Réaux's Historiettes, 78 LaForce's Mémoires, 79 and Richelieu). 80

Many of these works make the questionable assumption that López was a Jew or a converso. Francisque Michel's interesting study sheds light on the origin of thatconfusion: in Volume II of his Histoire desracesmaudites dela France et de l'Espagne [History of the Cursed Races of France and Spain] the author devotes several pages to the Expulsion of the Moriscos and their passage through France, and four pages (81-85) to López, whom he presents as a Morisco, but adds: "In Paris, even persons of above-average condition confuse Mohammedanism with Judaism and take Lopez for a Jew, although he was a

72 John Elliott, Richelieu and Olivares (Cambridge: Cambridge University Press, 1991), 116, 145; Hugon, Au service, 193, 375.

73 Baraude, Lopez.

74 Caro Baroja, Vidaspoco paralelas (con perdón de Plutarco)(Madrid:Turner), 1981,51-68.

75 Françoise Hildesheimer "Une créature de Richelieu: Alphonse Lopez, le Seigneur Hebreo" in Les juifs au regard de l'Histoire (Paris: Picard), 1985, 293-299.

76 Robert Sauzet "AlonsoLopez, procureur des Morisques Aragonais et agent de Richelieu (1582-1649)," in Actes du II Congrès International Chrétiens et musulmans à l'époque de la Renaissance (Zaghouan: Fondation Temimi), 1997, 213-219.

77 For instance the posthumous work of Marañón, Expulsióny diáspora, 85-88; Mercedes García-Arenal and Gerard Wiegers, Entre el Islamy el Occidente: Vida de Samuel Pallache, judío de Fez (Madrid: Siglo XXI), 1999, 158-161 [English translation: A Man of Three Worlds: Samuel Pallache, a Moroccan Jew in Catholic and Protestant Europe (Baltimore: Johns Hopkins), 2003, 116-119]; and Pelorson, "Le docteur."

78 Tallemant des Réaux, Les historiettes de Tallemant Des Réaux: mémoires pour servir à l'histoire du XVIIe siècle (Paris: A. Levavasseur), 1834-1835, II: 38-40.

79 La Force, Mémoires, vol. I.

80 Martial Avenel (ed.), Documents inédits sur l'histoire de France. Lettres, instructions diplomatiques et papiers d'État du Cardinal de Richelieu (Paris: Imprimerie Impériale), 1853-1874. 
Mohammedan. Is it not ironic that Moriscos should come from Spain only to be treated as Marranos? D' Aigrefeuille tells us that this label remained attached to families of that race [Moriscos] who settled in Languedoc."81

Anotherwriter,Jules Mathorez (1919), also devotes afew pages toLópezin Les étrangers en France sous l'Ancien Régime (Foreigners in France under the Ancien Régime) 82 and likewise considers him a Morisco.

More recently, Pierre Santoni has provided clear proof of López's Morisco origins and identifies him specifically as an Aragonese from the province of Zaragoza.83 Gregorio Marañón thought that he was from Granada, but this opinion is based solely on our protagonist's claim to be descended from the family of the Abencerrajes. The available documentary evidence makes him an Aragonese born in 1572 or 1582 who died in Paris on 21 October 1649 (thus, at the age of either 67 or 77).

We first hear of Alfonso López in 1602-1604: in those years he appears in documents of the Duke of La Force, Governor of Béarn, 84 as a negotiator and intermediary between the French authorities and the Moriscos. At this point he enters history as the procureur/procurador [agent or representative] of the Aragonese Moriscos who hoped to mount, with French help, an internal rebellioninSpaincombined withaninvasion from thenorth.85Hisarrival inFrance, as in the case of the two Moriscos we discussed earlier, preceded the decree of Expulsion from Spain.

OurMorisco appears once again in the course of his people's transitthrough southern France, and we can then follow him until his death in Paris. His biography still contains large lacunae between the date of his birth, 1572 or 1582, and the moment in 1610 when he can be securely placed in Toulouse: there he wasmanaging the arrangements for the Moriscos' embarkationanddefending their interests against abuses by the local people and some of their authorities. We do not know for certain just how he came to serve as the Moriscos' representative. He is called, unflatteringly, the soy disant procureur [self-styled agent] in documents published by Cardaillac from López's lawsuit against

81 “À Paris même des gens d'un rang au-dessus du vulgaire confondaient le mahométisme avec le judaïsme, voulant faire passer Lopez pour un juif, lui quiétait mahométan.Et puis ne suffisait-il pas que les Morisques vinssent d'Espagne pour être traités de Marranes? D'Aigrefeuillle nous apprend que cette désignation reste définitivement aux familles issues de cette race qui s'établirent en Languedoc": Michel, Histoire des races, II: 94-95.

82 Jules Mathorez, Les étrangers en France sous l'Ancien Régime (Paris: Champion), 1919, I: 168-171.

83 Santoni, "Le passage," 366-367.

84 La Force, Mémoires, I: 379-380.

85 “Mémoire adresséà Henri IV par les Morisques d'Espagne,"in Baraude, Lopez, 183-188. 
Pierre d'Augier, the officer in charge of embarking the Moriscos in Perpignan: hehad accused the Frenchman of stealing money from him and his charges. 86 But according to Francisque Michel, López was chosen for his post (together with two other men, Pedro Bibero and Tristán Oscén) by Morisco notables 87 Santoni describes, on the basis of unpublished documents, the process of naming several representatives of the Moriscos. 88

This was the first rung of the ladder that would lead him to stardom and fame: at the time his legitimacy in the eyes of the French authorities rested only on the fact that he belonged to the Morisco community, but his path to the summit would distance him from that community. He owed his ascent not to it - although he would use it as a springboard - but rather to the strategies that he employed and, above all, to the relationships that he forged with key individuals who would open the doors to Paris and the Court. In the course of defending the Moriscos' interests against d'Augier he had met the Marquis of Rambouillet, the French Ambassador to Spain (1618-1629), who introduced him at Court and made him known to the king's favourite, Concini, and above all to Concini's wife Leonora Galigai, who was the queen's confidante.

In Paris he settled in the Rue Saint-Honoré, in the capital's liveliest neighbourhood, the site of intense artisanal, commercial and financial activity and home also to a community of converts with whom he would become intimately connected.

López also took advantage of Louis XIII's marriage to the Spanish infanta Anne of Austria in 1615 as a means of entering Hispanophile circles at Court. Paradoxically, the fact of being a Spaniard (as he is described in the documents) would open those doors to him. As a member of a group expelled from Spain for being considered not Spanish (that is, not Catholic), but regarded as a Spaniard and presenting himself as such in a Hispanophobic France, he found his identity as a Morisco - rejected in his own country valued, with some limitations, in his land of exile. There his Morisco origin placed him among the enemies of Spain, a fundamental factor at a time when both powers were struggling to achieve hegemony in Europe. We should not

86 "Summary of the suit pending before the King's Privy Council between Jean d'Augier [...]. Against Alonce Loppe [sic], who calls himself the agent for the Moriscos of the land of Aragón [...]”("Sommaire du procès pendant au privéconseil du Roy entre Jean d'Augier [...]. Contre Alonce Loppe soy disant procureur des Morisques au pays d'Aragon [...]"), in Baraude, Lopez, 196.

87 Michel, Histoire des races, 81.

88 Santoni, "Le passage," 365-367. 
forget, however, that Moriscos could settlein France, even temporarily, only if they were Christians. 89

As to his religious beliefs - and in spite of speculations about his JudaismLópez, like many of his Morisco compatriots, seems to have practiced an outward Christianity. He boasted of eating pork frequently; but one of our chief sources about him, Tallemant des Réaux (whose father was his neighbor) tells us that "Inearly split my sides laughing, because my father lived nearby, to see him eating pork almost every day. No one considered him a better Christian because of that." 90

This is one of the most interesting facets of the spectacular career of this man, who eventually became the counselor, confidant and spy of Richelieu and one of the richest men in Paris (owner of jewels, gold, works of art, luxurious furnishings, etc.). Richelieu even entrusted him with strategic missions, among them the purchase of warships and arms in Holland, and a report on the reconstruction of the port of Le Havre whose general outline was followed later by Colbert in 1671.91 Wealso find him as the chief promoter for building the city of Richelieu, between Tours and Poitiers, a project that arose from a whim of the Cardinal's beginning in 1631.92 All this shows that our protagonist was able, through his relationships but also through his own merits, to rise to the summit of seventeenth-century French society under the protection of the all-powerful Richelieu.

It would be interesting to analyse the strategies that López and other Moriscos developed for integrating into a society in which, as descendants of both Moors and Spaniards, they were doubly foreign. López would succeed better than most, however: he obtained French nationality in 1630-1631 and eventually rose to noble rank.

Mercedes García-Arenal and Gerard Wiegers believe that López, who in France was taken to be either a Spanish Jew or a Morisco, serves as a good example of both groups of exiles from his native land. His highly unusual

89 Michel, Histoire des races, 92-94; Santoni, "Le passage," 371-376; ibid., "Les tournées de François de Beaumont pour l'expulsion des morisques de Provence (janvier-mars 1611)," Cahiers de la Méditerranée 79 (2009), 280-281.

90 "Jemecrevois de rire, car mon pèreétoit son voisin, de le voir manger du pourceaux quasi tous les jours. On nel'en croyoit pas meilleur chrétien pourcela": Tallemant, Les historiettes, 46.

91 Philippe Barrey, "Les débuts de la grande industrie havraise," in Recueil des publications de la Société Havraise d'Études Diverses A83 (1916), 34-35.

92 Baraude,Lopez,108;P.Raveau, "Undétailinéditdelaconstruction delavilledeRichelieu," Bulletin de la Société des Antiquaires de l'Ouest, 3 s., t.V (1919), 260-273. 
career shows how skilfully some descendants of both Jews and Moors trod a path of cultural ambiguity.

The three Morisco characters we have profiled were real persons, but their lives contained elements of the best fiction. As Luce López-Baralt has observed,93 Cervantes's Ricote, although he was imaginary, represented well those Moriscos who moved in and out of Spain before, during and after the Expulsion: supported by networks of solidarity that we are just beginning to identify, theyillustrate the Moriscodramaintheirown way and stand for exiles of all times and places who have had to create new lives far from their homes. Some managed on their own, while others took advantage of a variety of networks created by the Expulsion. It would be worthwhile to explore more fully the following topics: conversos of Jewish origin whohelped Moriscos to take their property in secret out of the country and into France; Morisco networks in France both before and after the Expulsion;94 collaboration between Moriscos and conversos 95 and between Moriscos and Protestants (by widening the paths first traced by Cardaillac); and remarkable individual Moriscos. These are the lines of inquiry that will be most fruitful for the history of the Moriscos in France.

The story of the Spanish Moriscos had its epilogue in Europe; in France it included these tales about the jealous man from Granada, the transvestite in Paris, and that fascinating chameleon, Alfonso López.

93 López-Baralt, La literatura,395-397.

94 López-Baralt, La literatura, 395-442, analyzes secret routes taken both out of and back into Spain by sixteenth-century Moriscos: toward Tunis and Turkey, passing through France and Italy. Her study completes Chapter 2 of Cardaillac's thesis Le passage des Morisques en Languedoc (Montpellier: Université Paul Valéry), 1970, 10-14.

95 Luis F. Bernabé Pons, "Notas sobre la cohesión de la comunidad morisca más allá de su expulsión de España," Al-Qanțara 29-2 (2008), 307-332, esp. 314-326 on France. The author and his co-author Jorge Gil Herrera expand these observations in their contribution to the present volume, a piece which explores the existence of supportive networks of both Moriscos and conversos in southern France before the Expulsion; these aided the exiles' transit to their ultimate destinations in the Maghreb. It is one of the most interesting chapters of the Moriscos' history inFrance, between theirrespectiveExpulsionsfrom Spain beginning in 1609 and from France beginning in 1610. 